\title{
Source Apportionment of Airborne Particles During Winter in Contrasting, Coastal Cities
}

\author{
Inoka Senaratne ${ }^{1}$, Francis M. Kelliher ${ }^{2 *}$ and Christopher Triggs ${ }^{3}$ \\ I. School of Geography and Environmental Science, The University of Auckland, \\ Private Bag 92019, Auckland, New Zealand. \\ 2. Manaaki Whenua - Landcare Research, P.O.Box 69, Lincoln, New Zealand. \\ 3. Department of Statistics, The University of Auckland, Private Bag 92019, Auckland, New Zealand.
}

\begin{abstract}
The coarse $(2.5-10 \mu \mathrm{m})$ and fine $(<2.5 \mu \mathrm{m})$ fractions of airborne particles were sampled during winter 2000 and 2001 in Auckland and Christchurch, New Zealand. Sampling was carried out using a versatile air pollution sampler (VAPS) and particle analyses for elemental concentrations utilized proton induced $\mathrm{x}$-ray emission (PIXE) and light reflection/transmission techniques. Emission source identification was by principal component factor analysis (PCFA) with Varimax rotation while the source apportionment used the absolute principal component analysis (APCA) receptor modeling method. The major emission sources identified were classified as sea spray (SS), suspended soil and road dust ( $\mathrm{SO} \& \mathrm{RD}$ ), domestic emissions (DE), and vehicle emissions (VE, diesel and petrol). In Auckland, source apportionment to SS, SO \& RD, DE, and VE emissions averaged 22, 42, 14 and 22 $\%$ respectively. The corresponding averages for Christchurch were 23, 29, 25, and $23 \%$. The colder Christchurch climate corresponded with nearly twice the DE contribution of Auckland. Containing a significant contribution from vehicles, SO \& RD made the highest contribution in both cities. In Auckland, as expected, road transport was considered the dominant source of $\mathrm{PM}_{10}$. Contrary to strong local perception, this is the first report to suggest that Christchurch's $\mathrm{PM}_{10}$ has a significant contribution from road transport during winter.
\end{abstract}

Keywords: versatile air pollution sampler (VAPS), proton induced x-ray emission (PIXE), principal component factor analysis (PCFA), absolute principal component analysis (APCA).

\footnotetext{
${ }^{*}$ Corresponding author. Fax: 64-3-325-3607.

E-mail address: KelliherF@LandcareResearch.Co.NZ
} 


\section{Introduction}

New Zealand generally enjoys good air quality. This reflects the country's low population density (only 15 people per $\mathrm{km}^{2}$ on average), geographical isolation in the South Pacific Ocean, the predominant westerly winds, the coastal location of cities and limited industrial activity (ARC, 1999). However, New Zealand's urban air quality can become potentially dangerous to the health of some people (ARC, 2002). For example, Auckland has a brownish haze that reduces visibility during cold and calm winter days (ARC, 1997; Senaratne and Shooter, 2004). Another city, Christchurch, has a wintertime smog problem (Spronken-Smith et. al., 2002). Suspended particulates are considered a main cause of poor air quality that can occur in these two cities. It is widely accepted that increasing $\mathrm{PM}_{10}$ (particles with diameter less than $10 \mu \mathrm{m}$ ) levels cause excess deaths and detrimental health effects (ARC, 2002). New Zealand has the fifth highest rate of chronic obstructive respiratory disease in the world (ARC, 2002).

The Auckland region is home to 1.2 million people. The region has $30 \%$ of New Zealand's population but only $2 \%$ of its land area (ARC, 2002). It has a temperate climate (1400 mm annual rain fall and an average air temperature of $16^{\circ} \mathrm{C}$ ). Auckland is New Zealand's most industrialized city, but industrial emissions are closely monitored by the local authorities and based on emission inventories it is estimated that the contribution from industrial emissions are less than $3 \%$ of the total emissions (ARC, 1999). The region has 650,000 vehicles and car ownership is growing at around twice the rate of the population growth (ARC, 1997; ARC, 2002). Christchurch is located $800 \mathrm{~km}$ south of Auckland on the east coast of the New Zealand's South Island. It has 0.36 million people, and its climate is significantly drier $(650 \mathrm{~mm}$ annual rain fall $)$ and cooler $\left(12{ }^{\circ} \mathrm{C}\right.$ average air temperature), especially in winter when domestic heating is essential. For Christchurch, on a typical winter day, solid fuel burning has been estimated to include 590 and 132 tonnes of wood and coal, respectively (CRC, 1997). The city has 336,296 vehicles or nearly one for every person including children (CCC, 2000).

Identifying the sources of $\mathrm{PM}_{10}$ and source apportionment is an essential precursor to achieving clean and healthy air. In this paper, we present elemental concentrations of airborne particles and, using a source - receptor model, deduce emission source apportionment of $\mathrm{PM}_{10}$ during two winters in contrasting coastal cities, Auckland and Christchurch, New Zealand.

\section{Experimental methods}

\subsection{Ambient air Sampling}

A versatile air pollution sampler (VAPS - model URG-3000H2, flow rate $32 \mathrm{~L} \mathrm{~min}^{-1}$ ) collected coarse $\left(\mathrm{PM}_{2.5-10}\right)$ and fine $\left(\mathrm{PM}_{2.5}\right)$ airborne particles on $47 \mathrm{~mm}$ polycarbonate filters (pore size $\left.0.4 \mu \mathrm{m}\right)$ at sampling sites in Auckland and Christchurch. Sampling height at Auckland was about $1.5 \mathrm{~m}$, while 
it was about $3 \mathrm{~m}$ at Christchurch. In Auckland, particulate samples were collected on alternative days between 23 May and 14 June 2000, July 2001 and on selected days of high particulate concentration during August 2001. Sampling in Christchurch was 2 July - 2 August 2000 and 18 June - 3 July 2001. Samples were collected over 12 hours on day and night bases. The number of samples collected during winter was 21 in Auckland and 27 in Christchurch. The winter samples seemed insufficient for source identification using the source-receptor model. Therefore, as well as these samples, 15 samples collected in Auckland during the summer of 2000/01 were used to identify potential $\mathrm{PM}_{10}$ emissions sources. Source apportionment did not include the summer samples.

\subsection{Description of sampling sites}

The Auckland sampling site was located at the Tamaki Campus of the University of Auckland, about $13 \mathrm{~km}$ southeast from the city's central business district. The site's terrain was gently undulating, and the vegetation was grass. A road of generally high vehicle density was about $20 \mathrm{~m}$ away to the west, and about $2 \mathrm{~m}$ downhill. A railroad line passed about $500 \mathrm{~m}$ to the east, and about 4 $\mathrm{m}$ downhill. A quarry was about $300 \mathrm{~m}$ away to the southwest, and a shipping container yard about $500 \mathrm{~m}$ to the south. Residential areas were about $1 \mathrm{~km}$ away to the southeast and northwest. The Tasman Sea was about $30 \mathrm{~km}$ to the east. The Pacific Ocean was $25 \mathrm{~km}$ to the west, but separated from it by the Hauraki Gulf located $5 \mathrm{~km}$ to the west.

The Christchurch sampling site was located next to Packe Street in a flat, residential area known as St. Albans. The city's central business district was $2 \mathrm{~km}$ to the southwest. About $25 \mathrm{~m}$ east and $40 \mathrm{~m}$ north, there were roads with high vehicle density during much of the day, except for weekends. The sea is about $5 \mathrm{~km}$ to the east, the Southern Alps $70 \mathrm{~km}$ to the west, and the 500 -m-tall Port Hills about $5 \mathrm{~km}$ to the south.

\subsection{Sample analyses}

Quantitative analyses were carried out for 16 elements: $\mathrm{Na}, \mathrm{Mg}, \mathrm{Al}, \mathrm{Si}, \mathrm{S}, \mathrm{Cl}, \mathrm{K}, \mathrm{Ca}, \mathrm{Ti}, \mathrm{Mn}, \mathrm{Fe}, \mathrm{Ni}$, $\mathrm{Cu}, \mathrm{Zn}, \mathrm{As}$, and $\mathrm{Pb}$, using PIXE. The filter samples were exposed to a beam of particles. This used a proton beam accelerated with 2.5 million volts from a van-der-Graaff accelerator and a $\mathrm{Si}(\mathrm{Li})$ detector (energy resolution $160 \mathrm{eV}$ at a target-detector angle $135^{\circ}$ ). The spectra were analyzed using Gupix Software (Maxwell et. al., 1995) to perform the de-convolution, as spectra consisted of many overlapping peaks (Trompetter and Markwitz, 2001). Calculation of the elemental concentrations also used the Gupix software, based on the number of counts in each peak for a given element.

Elemental carbon was quantitatively determined with a light reflection/transmission technique. A light emitting diode (LM10) produced white light that passed through a filter and was reflected with a polished Al reflector. The irradiance was measured with an IPL 10530 sensor. A blank filter was used to adjust the sensitivity potentiometer to full scale. The device was calibrated with the burning candle 
method (Cohen et al., 2000). Samples were mounted on acid washed (37 mm) slide holders.

To eliminate the problems associate with background concentrations of the filter media and determine the minimum detection level (MDL) of each element we analysed several blank filter papers in each batch of filters. The MDL was determined using the equation proposed by Miller and Miller (1993). For elemental concentrations less than the MDL, an estimate was made using half of the MDL. We also analysed an NIST SRM 1648 (urban particulate matter) sample in triplicate. According to PIXE, for $\mathrm{Na}, \mathrm{Mg}, \mathrm{Al}, \mathrm{S}, \mathrm{Cl}, \mathrm{K}, \mathrm{Ti}, \mathrm{Mn}, \mathrm{Fe}, \mathrm{Ni}, \mathrm{Cu}, \mathrm{Zn}, \mathrm{As}$, and $\mathrm{Pb}$, the elemental concentrations were within $20 \%$ of this standard. Unfortunately, the standard's $\mathrm{Si}$ and $\mathrm{Ca}$ concentrations have not been reported.

\subsection{Meteorology during the sampling period in the two cities}

Measurements of ambient temperature, wind speed and direction, relative humidity and rainfall were made continuously during particle sampling, and recorded as hourly averages. Air temperature and relative humidity were measured at $1 \mathrm{~m}$ above the ground. In Auckland, wind speed, wind direction and rainfall were measured about $1 \mathrm{~km}$ away from the VAPS to the southwest. Air temperature and relative humidity were measured about $5 \mathrm{~km}$ away to the east. In Christchurch, meteorological measurements were made next to the VAPS, except rainfall. Rainfall was measured 1 km away to the south.

In Auckland during particulate sampling, daily averages of air temperature, relative humidity, and wind speed were $12{ }^{\circ} \mathrm{C}, 80 \%$, and $3 \mathrm{~m} \mathrm{~s}^{-1}$, respectively. In Christchurch, corresponding values were 7 ${ }^{\circ} \mathrm{C}, 82 \%$, and $2 \mathrm{~m} \mathrm{~s}^{-1}$. In Auckland, rainfall was measured only for the period of sampling during winter 2000 when it was only $2 \mathrm{~mm}$. On days of sampling during the winters of 2000 and 2001, there was essentially no rain. In Christchurch, rainfall for the period that included sampling days totalled $46.5 \mathrm{~mm}$. However, on the days of particle sampling, there was no rain.

\subsection{Receptor modeling}

Principal component factor analysis (PCFA) with Varimax rotation was used to identify sources of the airborne particles sampled. Source apportionment was achieved using an absolute principal component analysis (APCA) receptor modeling method as described by Swietlicki et al. (1996). The analyses were performed using S-plus 2000. The method uses matrix notation written as:

$$
\mathrm{X}=\mathrm{AF}
$$

The matrix $\mathrm{X}$ is denoted $(\mathrm{m} \times \mathrm{n})$ with $\mathrm{m}$ for elemental concentration in $\mathrm{PM}_{10}$ expressed as a mass fraction ( $\mathrm{n} \mathrm{m}^{-3}$ ) and $\mathrm{n}$ for the $\mathrm{PM}_{10}$ collection date, $\mathrm{A}$ is $(\mathrm{m} \mathrm{x} \mathrm{p}$ ) containing a number, $\mathrm{p}$, of source profiles, and $\mathrm{F}$ is a matrix ( $\mathrm{p} \times \mathrm{n}$ ) of source contributions to the $\mathrm{PM}_{10}$ elemental composition. The 
number $\mathrm{p}$ is also the principal components retained in PCFA after Varimax rotation. Matrix A represents source profiles in the atmosphere at the receptor site where $\mathrm{PM}_{10}$ has been measured. Time has thus elapsed since the particle's emission from the source and there has been the potential for physical and chemical reactions in the atmosphere. The receptor model is used to estimate $\mathrm{A}$ and $\mathrm{F}$ such that $\mathrm{X}$ is reproduced to a satisfactory degree of accuracy.

To allow each of the 16 measured elements to have equal weight in the modeling, the concentration data are normalised which leads to:

$$
\mathrm{A}=\mathrm{S}_{\mathrm{x}} \mathrm{B} \mathrm{S}_{\mathrm{f}}^{-1}
$$

where $S_{x}$ is a diagonal $(\mathrm{m} \times \mathrm{m})$ matrix containing the standard deviations of $\mathrm{m}, \mathrm{B}$ is $(\mathrm{m} \times \mathrm{p})$ containing normalized values of $\mathrm{m}$ obtained by the Varimax rotated PCFA, and $\mathrm{S}_{\mathrm{f}}^{-1}$ is the inverse diagonal ( $\mathrm{p}$ x p) matrix containing standard deviations of $\mathrm{F}$, the unknown source contributions. To be tractable, equation (2) is rearranged to:

$$
\mathrm{A}^{\prime}=\mathrm{S}_{\mathrm{x}} \mathrm{B}
$$

where $A^{\prime}$ is equal to $\left(A S_{f}\right)$, the matrix of absolute source profiles, with units of $n g \mathrm{~m}^{-3}$ like $S_{x}$. Knowing $A^{\prime}=\left(\mathrm{A} \mathrm{S}_{\mathrm{f}}\right)$, we define $\mathrm{F}^{\prime}$, the matrix of absolute source contributions, as:

$$
\mathrm{F}^{\prime}=\mathrm{F} \mathrm{S} \mathrm{S}_{\mathrm{f}}^{-1}
$$

Combination of A' and F' yields $\mathrm{X}$ according to:

$$
A^{\prime} F^{\prime}=\left(A S_{f}\right)\left(F S_{f}^{-1}\right)=A F=X
$$

Multivariate receptor models yield source profiles and include transformations during particle transport in the atmosphere (Swietlicki et al., 1996). Source profiles, the average influence $\mathrm{C}_{\mathrm{ik}}$ from each source $\mathrm{k}$ and element $\mathrm{i}, \mathrm{Cbar}_{\mathrm{ik}}$, were estimated using APCA and the Kemp (1984) equation:

$$
\operatorname{Cbar}_{i \mathrm{k}}=\left\{\left(\operatorname{modb}_{\mathrm{ik}}\right) / \mathrm{w}_{\mathrm{i}}\right\} \mathrm{xbar}_{\mathrm{i}}
$$

where $\mathrm{w}_{\mathrm{i}}=\operatorname{sqrt}\left(1-\mathrm{h}^{2}{ }_{\mathrm{i}}\right)+\sum_{(\mathrm{k}=1 \ldots \mathrm{p})}\left(\operatorname{modb}_{\mathrm{ik}}\right), \mathrm{xbar}_{\mathrm{i}}$ is the measured mean mass of element $\mathrm{i}, \operatorname{sqrt}\left(1-\mathrm{h}^{2}{ }_{\mathrm{i}}\right)$ the square root of $\left(1-h^{2}{ }_{i}\right), h^{2}$ the communality value, and modb $b_{i k}$ the modulus of $B$, the $m x p$ matrix of normalized mass fractions obtained earlier. 


\section{Results and discussion}

\subsection{Sources of airborne $P M_{10}$}

Emission sources were first identified using elemental analysis data from the two cities. Some samples included elemental concentrations below the MDL. These included $\mathrm{Ni}, \mathrm{Cu}, \mathrm{Zn}, \mathrm{Pb}$ and $\mathrm{EC}$ in the coarse fraction of the majority of samples and $\mathrm{Mg}, \mathrm{Si}$ and $\mathrm{Ti}$ in the fine fraction. Descriptive statistics of the particulate elemental concentrations from the two cities are given in Tables $1 \mathrm{a}$ and $\mathrm{b}$. PCFA with Varimax rotation was performed after combining the data (winter and summer) from both cities in order to obtain maximum number of sources. Regards the emission sources, particles in the coarse fraction are generated mainly by mechanical processes such as wave breaking in the sea, and rising dust from the earth's surface (Brimblecombe, 1996; Pinto, 2000, Markowicz et al., 2002). The majority of the particles from combustion sources are in the fine fraction (Brimblecombe, 1996; Pinto, 2000). Therefore, the elemental composition of the coarse and fine fractions was used to deduce sources of the airborne particulates sampled. Since $\mathrm{PM}_{10}$ comprises two components, $\mathrm{PM}_{2.5-10}$ (coarse) and $\mathrm{PM}_{2.5}$ (fine), a combination of the elemental concentrations of these two fractions was considered more useful. Thus a combination of the following elements were selected for the PCFA to deduce the sources: Coarse fraction - Na, Al, Al, Si, S, Cl, K, Ca, Mn, and Fe; Fine fraction - Na, Al, S, Cl, K, Ca, $\mathrm{Mn}, \mathrm{Fe}, \mathrm{Ni}, \mathrm{Cu}, \mathrm{Zn}, \mathrm{As}, \mathrm{Pb}$, and EC.

This analysis allowed us to deduce six significant sources affecting the receptor sites that accounted for $86 \%$ of the variance (Table 2), as well as their chemical and physical nature. The next step was identification of these sources that utilized knowledge of the elemental profiles from a separate study (Senaratne, 2003) and the literature (Sharma and Patil, 1994; Chow, 1995; Harrison et al., 1996; Trompetter et al., 2002). We acknowledge that the sources assigned to principal components (PC) were not pure, but they are the most probable sources based on their elemental profiles. However, chemical composition according to the factor loadings was attributed to the most likely PC of $\mathrm{PM}_{10}$ (combination of the coarse (c) and fine (f) fractions) as: PC1 - High factor loadings for $\mathrm{Al}$ (c), $\mathrm{Si}$ (c), $\mathrm{Ca}$ (c), $\mathrm{Mn}$ (c), and Fe (c) together with $\mathrm{Mn}$ (f), Fe (f), $\mathrm{Ca}$ (f), K (c), Ni (f), Cu (f), Zn (f) and EC (f) indicated the source was suspended soil and road dust, mainly in the coarse fraction, PC2 - High factor loadings for $\mathrm{Na}$ (c), S (c), Cl (c), K (c), Cl (f) and $\mathrm{Na}$ (f) strongly suggested this source was sea spray. PC3 - High factor loadings for K(f), As(f), Pb(f) and EC(f) and Zn (f), Cu (f), S (f), K (c), and Ni (f) strongly indicated that this source was domestic combustion emissions, PC4 High factor loadings for $\mathrm{Al}(\mathrm{f}), \mathrm{Ca}(\mathrm{f}), \mathrm{Fe}(\mathrm{f})$ and $\mathrm{Mn}(\mathrm{f})$ with $\mathrm{Al}$ (c), $\mathrm{Si}$ (c) suggests that this source was of crustal origin; PC4 was more enriched with the fine fraction elements ( $\mathrm{Na}, \mathrm{Ni}, \mathrm{Cu}, \mathrm{Zn}$ ), so it was attributed to the fine fraction of the suspended soil and road dust source, PC5 - High factor loadings for $\mathrm{S}(\mathrm{f}), \mathrm{Cu}(\mathrm{f}), \mathrm{Na}(\mathrm{f})$ with $\mathrm{K}(\mathrm{f}), \mathrm{Mn}(\mathrm{f}), \mathrm{Zn}(\mathrm{f}), \mathrm{Pb}(\mathrm{f}), \mathrm{EC}(\mathrm{f})$ suggest that this source was diesel combustion emissions, PC6 - High factor loadings for $\mathrm{Ni}(\mathrm{f})$ and $\mathrm{Na}(\mathrm{f})$ together with $\mathrm{K}(\mathrm{f}), \mathrm{Al}(\mathrm{f}), \mathrm{Mn}(\mathrm{f})$, $\mathrm{Cu}(\mathrm{f}), \mathrm{As}(\mathrm{f})$ and $\mathrm{Pb}(\mathrm{f})$ suggest that the source was petrol emissions. 
Table 1. Statistics of elemental concentrations ( $\mathrm{ng} \mathrm{m}^{-3}$, minimum detection limit in brackets) in the $\mathrm{PM}_{10}$ coarse and fine fractions $(2.5-10 \mu \mathrm{m}$ and $<2.5 \mu \mathrm{m})$ for 21 samples from Auckland (top table) and 27 from Christchurch. Abbreviations are used for median, med., standard deviation, Std., minimum, Min., maximum, Max, and elemental carbon, EC.

\begin{tabular}{cccccc|ccccc}
\hline \multicolumn{7}{c}{ Coarse fraction } & \multicolumn{5}{c}{ Fine fraction } \\
\hline & Mean & Med. & Std. & Min. & Max. & Mean & Med. & Std. & Min. & Max. \\
\hline $\mathrm{Na} \mathrm{(63)}$ & 610 & 500 & 470 & 130 & 1710 & 330 & 220 & 200 & 130 & 660 \\
$\mathrm{Mg}(32)$ & 190 & 160 & 90 & 60 & 470 & 130 & 100 & 60 & 60 & 260 \\
$\mathrm{Al}(26)$ & 210 & 150 & 160 & 20 & 510 & 80 & 40 & 90 & 20 & 410 \\
$\mathrm{Si}(70)$ & 520 & 340 & 460 & 60 & 1400 & 120 & 90 & 100 & 30 & 450 \\
$\mathrm{~S} \mathrm{(10)}$ & 270 & 230 & 160 & 60 & 670 & 290 & 240 & 160 & 70 & 590 \\
$\mathrm{Cl}(13)$ & 1260 & 570 & 1260 & 40 & 3860 & 170 & 110 & 200 & 20 & 910 \\
$\mathrm{~K}(18)$ & 70 & 60 & 40 & 20 & 180 & 60 & 50 & 50 & 10 & 190 \\
$\mathrm{Ca}(7)$ & 220 & 170 & 200 & 20 & 710 & 40 & 30 & 30 & 10 & 130 \\
$\mathrm{Ti}(1)$ & 34.5 & 24.0 & 31.3 & 2.3 & 123.1 & 6.9 & 7.0 & 4.4 & 2.5 & 18.4 \\
$\mathrm{Mn}(1)$ & 6.3 & 2.6 & 7.8 & 0.5 & 30.4 & 3.0 & 1.0 & 3.7 & 0.5 & 14.8 \\
$\mathrm{Fe}(12)$ & 320 & 210 & 290 & 18 & 920 & 80 & 60 & 60 & 8.3 & 200 \\
$\mathrm{Ni}(2)$ & 3.5 & 2.9 & 2.1 & 1.2 & 8.3 & 3.2 & 2.9 & 1.9 & 1.0 & 7.5 \\
$\mathrm{Cu}(1)$ & 5.3 & 5.0 & 3.2 & 1.0 & 12.0 & 3.7 & 3.6 & 2.3 & 1.1 & 9.3 \\
$\mathrm{Zn}(1)$ & 20.8 & 10.4 & 28.2 & 1.0 & 118 & 31.9 & 10.0 & 49.5 & 0.6 & 195.3 \\
$\mathrm{As}(1)$ & 2.8 & 2.5 & 1.5 & 0.5 & 6.9 & 6.5 & 2.4 & 7.7 & 0.8 & 30.0 \\
$\mathrm{~Pb}(7)$ & 6.4 & 6.1 & 5.5 & 3.5 & 21.5 & 8.7 & 6.2 & 11.2 & 3.5 & 41.2 \\
$\mathrm{EC} \mathrm{(51)}$ & 800 & 900 & 600 & 60 & 2100 & 3700 & 3000 & 2500 & 300 & 8300 \\
\hline
\end{tabular}

\begin{tabular}{cccccc|ccccc}
\hline \multicolumn{7}{c}{ Coarse fraction } & \multicolumn{5}{c}{ Fine fraction } \\
\hline & Mean & Med. & Std. & Min. & Max. & Mean & Med. & Std. & Min. & Max. \\
\hline $\mathrm{Na} \mathrm{(63)}$ & 1000 & 650 & 855 & 120 & 3170 & 390 & 250 & 270 & 65 & 980 \\
$\mathrm{Mg}(32)$ & 150 & 105 & 110 & 28 & 355 & 70 & 80 & 30 & 30 & 190 \\
$\mathrm{Al} \mathrm{(26)}$ & 120 & 80 & 95 & 12 & 430 & 95 & 100 & 165 & 12 & 900 \\
$\mathrm{Si}(70)$ & 350 & 210 & 305 & 35 & 1310 & 130 & 70 & 320 & 15 & 1700 \\
$\mathrm{~S} \mathrm{(10)}$ & 305 & 230 & 170 & 105 & 735 & 450 & 390 & 250 & 65 & 970 \\
$\mathrm{Cl}(13)$ & 3210 & 2080 & 2810 & 60 & 8830 & 460 & 445 & 355 & 30 & 1275 \\
$\mathrm{~K}(18)$ & 110 & 90 & 55 & 25 & 200 & 245 & 185 & 185 & 40 & 790 \\
$\mathrm{Ca}(7)$ & 150 & 135 & 85 & 35 & 400 & 35 & 20 & 25 & 8 & 135 \\
$\mathrm{Ti}(1)$ & 11.0 & 6.7 & 9.3 & 0.5 & 46.1 & 9.0 & 13.0 & 7.3 & 0.5 & 28.2 \\
$\mathrm{Mn}(1)$ & 2.0 & 0.5 & 2.6 & 0.5 & 10.0 & 1.6 & 1.1 & 1.7 & 0.5 & 7.7 \\
$\mathrm{Fe} \mathrm{(12)}$ & 130 & 85 & 125 & 20 & 545 & 40 & 20 & 70 & 6 & 355 \\
$\mathrm{Ni}(2)$ & 1.5 & 1.5 & 0.7 & 1.0 & 3.8 & 2.4 & 3.2 & 1.2 & 0.7 & 3.7 \\
$\mathrm{Cu}(1)$ & 3.8 & 3.6 & 3.5 & 0.5 & 14.8 & 5.4 & 3.4 & 5.1 & 0.5 & 20.4 \\
$\mathrm{Zn}(1)$ & 11.5 & 7.7 & 10.8 & 1.9 & 45.1 & 41.9 & 30.6 & 42.0 & 5.1 & 205 \\
$\mathrm{As}(1)$ & 6.8 & 9.6 & 4.1 & 0.5 & 11.0 & 29.4 & 21.1 & 22.0 & 0.5 & 80.6 \\
$\mathrm{~Pb}(7)$ & 17.6 & 25.5 & 10.7 & 3.7 & 29.3 & 62.8 & 56.0 & 60.2 & 4.2 & 255 \\
$\mathrm{EC} \mathrm{(51)}$ & 900 & 700 & 750 & 25 & 3500 & 8010 & 7100 & 4840 & 1765 & 24160 \\
\hline
\end{tabular}


Table 2. Rotated component matrix of factor loadings for combined Auckland and Christchurch coarse and fine fractions of $\mathrm{PM}_{10}$ samples ( $>0.5$ in bold, $<0.1$ not included). The sources were classified: $\mathrm{PC} 1$ as suspended soil/road dust in the coarse fraction (SO/RD)c, PC2 as sea spray (SS), PC3 as domestic emissions (DE), PC4 as (SO/RD)f with $\mathrm{f}$ for fine fraction, PC5 as diesel fueled vehicle emissions (Diesel), PC6 as petrol fueled vehicle emissions (Petrol). The communality is designated Commun. Element symbols include EC for elemental carbon. For each PC, the percentage of variance explained by analysis and cumulative values from left to right are given.

\begin{tabular}{|c|c|c|c|c|c|c|c|}
\hline & $\begin{array}{c}\mathrm{PC} 1 \\
(\mathrm{SO} / \mathrm{RD}) \mathrm{c}\end{array}$ & $\begin{array}{l}\text { PC2 } \\
\text { (SS) }\end{array}$ & $\begin{array}{l}\mathrm{PC} 3 \\
\text { (DE) }\end{array}$ & $\begin{array}{c}\mathrm{PC} 4 \\
(\mathrm{SO} / \mathrm{RD}) \mathrm{f}\end{array}$ & $\begin{array}{c}\text { PC5 } \\
\text { (Diesel) }\end{array}$ & $\begin{array}{c}\text { PC6 } \\
\text { (Petrol) }\end{array}$ & Commun. \\
\hline \multicolumn{8}{|l|}{ Coarse fraction } \\
\hline $\mathrm{Na}$ & & 0.92 & & & & 0.10 & 0.91 \\
\hline $\mathrm{Al}$ & 0.90 & & 0.12 & 0.22 & 0.13 & 0.23 & 0.94 \\
\hline $\mathrm{Si}$ & 0.88 & & 0.15 & 0.21 & 0.16 & 0.26 & 0.93 \\
\hline $\mathrm{S}$ & 0.09 & 0.85 & & & & & 0.87 \\
\hline $\mathrm{Cl}$ & 0.13 & 0.98 & 0.12 & & & & 0.95 \\
\hline $\mathrm{K}$ & 0.48 & 0.73 & 0.19 & & 0.16 & 0.20 & 0.86 \\
\hline $\mathrm{Ca}$ & 0.89 & 0.28 & & 0.18 & & & 0.91 \\
\hline $\mathrm{Mn}$ & 0.84 & & & 0.12 & & & 0.81 \\
\hline $\mathrm{Fe}$ & 0.98 & & & 0.19 & & & 0.96 \\
\hline \multicolumn{8}{|l|}{ Fine fraction } \\
\hline $\mathrm{Na}$ & 0.13 & 0.46 & & 0.19 & 0.39 & 0.55 & 0.85 \\
\hline $\mathrm{Al}$ & 0.19 & & & 0.68 & & 0.16 & 0.81 \\
\hline $\mathrm{S}$ & 0.13 & & 0.35 & & 0.91 & & 0.89 \\
\hline $\mathrm{Cl}$ & & 0.68 & & & & & 0.66 \\
\hline $\mathrm{K}$ & & & 0.88 & & 0.19 & 0.20 & 0.89 \\
\hline $\mathrm{Ca}$ & $\mathbf{0 . 5 3}$ & 0.16 & & 0.73 & & & 0.87 \\
\hline $\mathrm{Mn}$ & 0.61 & & 0.13 & 0.47 & 0.10 & 0.18 & 0.70 \\
\hline $\mathrm{Fe}$ & 0.59 & 0.12 & 0.12 & 0.73 & & & 0.88 \\
\hline $\mathrm{Ni}$ & 0.38 & & 0.17 & 0.26 & & 0.84 & 0.94 \\
\hline $\mathrm{Cu}$ & 0.25 & & 0.41 & 0.12 & 0.50 & 0.13 & 0.74 \\
\hline $\mathrm{Zn}$ & 0.47 & & 0.60 & 0.12 & 0.14 & & 0.70 \\
\hline As & & & 0.88 & & & 0.15 & 0.87 \\
\hline $\mathrm{Pb}$ & & & 0.81 & & 0.16 & 0.18 & 0.79 \\
\hline $\mathrm{EC}$ & 0.26 & & 0.91 & & 0.14 & & 0.91 \\
\hline$\%$ of variance for $\mathrm{PC}$ & 36 & 20 & 14 & 6 & 5 & 5 & \\
\hline Cumulative $\%$ & 36 & 56 & 70 & 76 & 81 & 86 & \\
\hline
\end{tabular}

Crustal element concentrations such as $\mathrm{Ca}$ and $\mathrm{Al}$ in the coarse fraction had a significant inverse relationship with wind speed. Concentrations of these elements were thus highest under calm conditions. This supported our deduction that the crustal elements came from re-suspension of soil/road dust, rather than transport from elsewhere by the wind. Supporting this logic, the sea virtually surrounded the Auckland sampling site and at Christchurch, the wind mostly came from the seaward direction. We detected little $\mathrm{Ca}$ and no Al in sea spray (Table 3). For the coarse fraction of $\mathrm{PM}_{10}$, on average in both cities, the concentration of $\mathrm{Ca}$ exceeded that of $\mathrm{Al}$ (Table 1). The mean $\mathrm{Ca} / \mathrm{Al}$ ratio was 1.05 and 1.25 in Auckland and Christchurch, respectively. Corresponding $\mathrm{Ca} / \mathrm{Al}$ ratios for Christchurch were 1.78, 1.28 and 1.33 according to Thompson and Fisher (1998), Senaratne (1999) and Scott (2004). 
Table 3. Airborne particle elemental source profiles from the absolute principal component analysis, combining Auckland and Christchurch's coarse and fine $\mathrm{PM}_{10}$ data. Sources were classified: suspended soil/road dust in the coarse and fine fractions as (SO/RD)c and ( $\mathrm{SO} / \mathrm{RD}) \mathrm{f}$, sea spray as $\mathrm{SS}$, domestic emissions as DE, diesel fueled vehicle emissions as Diesel, and petrol fueled vehicle emissions as Petrol. Element symbols include EC for elemental carbon. For each element, the percentage of all measured is shown, so each column's sum is 100.

\begin{tabular}{ccccccc}
\hline & $(\mathrm{SO} / \mathrm{RD}) \mathrm{c}$ & $\mathrm{SS}$ & $\mathrm{DE}$ & $(\mathrm{SO} / \mathrm{RD}) \mathrm{f}$ & Diesel & Petrol \\
\hline Coarse fraction & & & & & & \\
\hline $\mathrm{Na}$ & & 18.6 & & & & 18.8 \\
$\mathrm{Al}$ & 6.6 & & 0.4 & 7.2 & 1.6 & 7.0 \\
$\mathrm{Si}$ & 15.6 & & 1.3 & 16.3 & 4.8 & 18.4 \\
$\mathrm{~S}$ & 1.0 & 5.4 & & & 1.9 & \\
$\mathrm{Cl}$ & & 64.9 & & & & 9.2 \\
$\mathrm{~K}$ & 1.5 & 1.0 & 0.3 & 1.3 & 0.8 & 2.4 \\
$\mathrm{Ca}$ & 6.8 & 0.9 & & 6.4 & 1.1 & 2.2 \\
$\mathrm{Mn}$ & 0.2 & & & 0.1 & & \\
$\mathrm{Fe}$ & 10.4 & & 0.3 & 9.8 & 0.7 & 0.8 \\
& & & & & & \\
Fine fraction & & & & & & \\
$\mathrm{Na}$ & 1.8 & 2.8 & & 10.2 & 8.6 & 30.2 \\
$\mathrm{Al}$ & 0.8 & 0.0 & & 12.2 & 0.1 & 2.9 \\
$\mathrm{~S}$ & 1.9 & 0.2 & 2.4 & 0.7 & 22.1 & \\
$\mathrm{Cl}$ & & 6.0 & 0.7 & 6.0 & & \\
$\mathrm{~K}$ & & & 2.7 & 1.0 & 2.0 & 4.6 \\
$\mathrm{Ca}$ & 0.8 & 0.1 & & 4.7 & 0.1 & 0.5 \\
$\mathrm{Mn}$ & 0.1 & & & 0.2 & & 0.1 \\
$\mathrm{Fe}$ & 1.4 & & 0.1 & 8.4 & 0.3 & 0.4 \\
$\mathrm{Ni}$ & & & & 0.1 & & 0.4 \\
$\mathrm{Cu}$ & & & & 0.1 & 0.1 & 0.1 \\
$\mathrm{Zn}$ & 0.5 & & 0.3 & 0.5 & 0.3 & 0.4 \\
$\mathrm{As}$ & & & 0.3 & & & 0.4 \\
$\mathrm{~Pb}$ & 0.1 & & 0.5 & 0.3 & 0.4 & 1.0 \\
$\mathrm{EC}$ & 50.4 & & 90.5 & 14.5 & 54.9 & \\
\hline
\end{tabular}

Table 4. Source apportionment from absolute principal component analysis for the Auckland and Christchurch $\mathrm{PM}_{10}$ samples. Data shown are mean percentage contributions from the six sources identified \pm one standard deviation. Sources were classified: sea spray as SS, suspended soil/road dust in the coarse and fine fractions as (SO/RD)c and (SO/RD)f, domestic emissions as DE, diesel fueled vehicle emissions as Diesel, and petrol fueled vehicle emissions as Petrol.

\begin{tabular}{ccccccc}
\hline & SS & (SO/RD)c & (SO/RD)f & DE & Diesel & Petrol \\
\hline Christchurch & $23 \pm 11$ & $20 \pm 5$ & $9 \pm 6$ & $25 \pm 9$ & $15 \pm 3$ & $8 \pm 1$ \\
Auckland & $22 \pm 12$ & $29 \pm 8$ & $13 \pm 4$ & $14 \pm 5$ & $14 \pm 2$ & $8 \pm 1$ \\
\hline
\end{tabular}


For the coarse and fine fractions of $\mathrm{PM}_{10}$, mean $\mathrm{Cl} / \mathrm{Na}$ ratios were 2.07 and 0.52 for Auckland and 3.21 and 1.18 for Christchurch (Table 1). In seawater, the mass ratio of $\mathrm{Cl} / \mathrm{Na}$ is 1.79 . We acknowledge that most $\mathrm{Cl}$ is volatile and $\mathrm{Na}$ is not, so comparison of the seawater and coarse fraction $\mathrm{Cl} / \mathrm{Na}$ ratios supported our argument of anthropogenic contributions to the $\mathrm{PM}_{10}$. Consistently, lower ratios were obtained for the $\mathrm{PM}_{10}$ fine fraction and vehicle emissions are mostly comprised of fine particulate matter according to Brimblecombe (1996) and Pinto (2000). In PC2 (sea spray), the coarse and fine fraction factor loading $\mathrm{Cl} / \mathrm{Na}$ ratios were 1.07 and 1.48, respectively. In Wellington, New Zealand, corresponding ratios were 1.06 and 1.04 and 1.03 and 0.98 according to Davy et al (2002) and Markwitz et al., (2003). In PC1, PC4, PC5 and PC6, the fine fraction $\mathrm{Cl} / \mathrm{Na}$ ratio was negligible as the factor loadings for $\mathrm{Cl}(\mathrm{f})$ were $<0.1$. This also suggested that $\mathrm{Na}$ (f) from these sources came from anthropogenic emissions (most probably vehicles), not sea spray. Ooki et al. (2002) reported that the $\mathrm{PM}_{10}$ fine fraction $\mathrm{K} / \mathrm{Na}$ ratio can indicate anthropogenic sources. For PC5 and PC6 in Auckland and Christchurch, this ratio was about twice that of PC2 (sea spray). Our direct emission samples showed that the $\mathrm{K} / \mathrm{Na}$ ratio for sea spray was about 15 times lower than for diesel and petrol combustion emissions (data not shown). The different ratios obtained for diesel and petrol emissions were useful in assigning PC5 and PC6 to diesel and petrol combustion sources. According to Senaratne (2003) and Trompetter et al. (2002), petrol and diesel combustion emissions had high percentages of $\mathrm{Na}$ (43\% and $29 \%$, respectively). We believe that high factor loadings for $\mathrm{Na}$ (f) combined with low factor loadings for $\mathrm{Cl}$ (f) identified vehicle emissions sources.

This study suggested that industrial emissions were not a significant source in the two cities. Senaratne (2003) reported data from an industrialized South Auckland suburb (Otara) that yielded the similar principal components reported here for the Tamaki site. This was reassuring because there is little industry in these cities and industrially produced goods are mostly imported from Asia.

Wang (2002) also reported sources of $\mathrm{PM}_{10}$ during winter in Auckland and Christchurch. $\mathrm{He}$ analysed water-soluble ionic species using a source-receptor model. Sources included sea spray, soil, domestic and vehicle emissions, and a component rich in $\mathrm{NH}_{4}{ }^{+}$that was thought to come from soil and/or biomass burning. The sources of $\mathrm{PM}_{10}$ were determined in Wellington, New Zealand. Trompetter et al. (2000 a,b) used a GENT sampler to collect $\mathrm{PM}_{10-2.5}$ and $\mathrm{PM}_{2.5}$. PIXE and light reflection/transmission analyses yielded total elemental concentrations and identified five sources as sea salt, soil, smoke, industry, and " bromine". The bromine was thought to be from a vehicle source. In contrast with Auckland and Christchurch, industrial sources were considered significant in Wellington. The key elements that identified these sources were $\mathrm{Sc}, \mathrm{Cr}, \mathrm{Fe}$, and $\mathrm{EC}$, and these were mostly below the MDL for our samples. In another Wellington study, soil and sea salt were major sources of the coarse $\left(\mathrm{PM}_{2.5-10}\right)$ fraction and combustion, sulfur, and sea salt major sources of the fine $\left(\mathrm{PM}_{2.5}\right)$ fraction (Davy et al., 2002).

The sources of $\mathrm{PM}_{10}$ have been determined in Australian cities that have populations comparable to those of Auckland and Christchurch. For example, Chan et al., (1999) reported source apportionment of $\mathrm{PM}_{2.5}$ and $\mathrm{PM}_{10}$ in Brisbane. The major sources were soil and road dust, motor vehicle emissions, 
sea salt, cement and mineral processing industries contributing $\mathrm{Ca}$ and $\mathrm{Ti}$ rich compounds, and biomass burning giving elemental carbon and secondary products. Source apportionment of fine particles in the Wollongong-Port Kembla area identified their sources as industrial emissions, emissions from copper smelting and steel making, sea salt, and road dust (comprising both soil and motor vehicle emissions) (Huo et al., 1999). Although Australia and New Zealand are located in the same region known as Oceania, there are significant differences between the two countries. For example, industrial emissions play a more significant role in Australia. Since leaded petrol is no longer used in New Zealand, the use of leaded petrol in Australia further confounds comparison of data from the two countries. Biomass burning and bush fires are significant sources of airborne particulates in Australia because of the generally drier climate, but not in New Zealand.

Asia is the closest adjoining region to New Zealand. However, high and low population densities are features of Asian and New Zealand cities. In Asian cities, the sources of $\mathrm{PM}_{10}$ are variable. Industrial and economic diversity complicate synthesis on a regional basis. A factor analysis-multiple regression model was used in the Tokyo metropolitan area. Varimax rotated factor analysis identified five sources including refuse incineration, soil and automobiles, secondary particles, sea salt and a steel mill (Okamoto et al., 1990). In Hong Kong, secondary ammonium sulfate, chloride depleted marine aerosols, marine aerosols, crustal/soil dust, non-ferrous smelters, vehicle emissions, particulate bromide, particulate copper, fuel oil burning and an unexplained residual were identified by source apportionment using positive matrix factorization (Lee et al., 1999). In Beijing, six major sources were identified including soil dust, construction dust, secondary source (by photochemical action), biomass burning, motor vehicles and coal burning (Song et al., 2002). In other Chinese cities, Zhang et al. (2004) used a Chemical Mass balance model (CMB) for source apportionment. Their major sources were fugitive dust, coal burning, industrial emissions, and vehicle exhaust. In Xian, Zhang and An (2004) used APCA for $\mathrm{PM}_{10}$ analysed with PIXE and reported four major contributors to the fine fraction were coal combustion, motor vehicle and fugitive and mineral dust. In Ho Chi Minh City, Vietnam, Varimax rotation factor analysis identified six major sources including resuspended soil/road dust, motor vehicles, As-rich source, cement dust, road dust of local traffic origin and biomass burning (Hien et al., 1999). In Dhaka, Bangladesh, the Positive matrix factorization (PMF) method identified eight major sources including re-suspended soil dust, motor vehicles, construction work, sea salt, refuse burning, natural gas/diesel burning, metal smelting and two-stroke engines (Biswas et al., 2001). Source apportionment of fine particles in Delhi, Kolkata and Mumbai, India identified five primary sources including gasoline, diesel, road dust, coal and biomass burning (Worldbank1, 2004). In another study in Mumbai, re-suspended dust, refuse and vegetation burning, sea salt and road traffic were identified as the major sources (Worldbank2, 2004). 


\subsection{Estimation of source profiles using the absolute principal component analysis (APCA) model}

The $\mathrm{PM}_{10}$ source profiles, from APCA, eqn (6) and the combined Christchurch and Auckland samples, are elemental masses expressed as percentages of the total based on the measured elemental concentrations, not the total sample mass (Table 3). Similarities were found between our source profiles for sea spray, soil, and domestic emissions and those for Wellington reported by Trompetter et al. (2002). However the Wellington soil source had a very high level of S and negligible Fe, whereas our soil and road dust had opposite levels of S and Fe as also reported by Senaratne (2003) and Senaratne and Shooter (2004). Although the Wellington "motor vehicle" profile had a high level of elemental carbon (EC), there was no evidence of S. Our direct emission samples from petrol combustion were brown whereas the diesel combustion emissions samples were black indicating a high level of EC. Trompetter et al. (2002) made the same observations. However, we also found S to be a key and abundant element of diesel combustion emissions. According to Table 3, in agreement with the data of Trompetter et al. (2002), $\mathrm{Na}$ is a key element of the petrol combustion emission profile.

The DE source elemental profile was dominated by EC (90\%) and EC was $>50 \%$ for the (SO/RD)c and diesel sources. Diesel combustion is known to be a major source of EC (Chow, 1995; HLTH350, 2002), consisting mainly of EC and organic carbon $<5 \mu \mathrm{m}$ (Mayer, 2000). These ultrafine nuclei particles comprise EC coated with adsorbed hydrocarbon (HC) materials, notably PAHs. After emission, the nuclei particles rapidly stick to each other to form larger agglomerated particles (HLTH350, 2002) that are readily deposited onto surfaces such as soil. The high percentage of EC in the $(\mathrm{SO} / \mathrm{RD}) \mathrm{c}$ profile could represent deposited EC from diesel combustion emissions and domestic emissions may have also contributed.

\subsection{Source apportionment of the VAPS coarse and fine fractions using APCA for Christchurch and Auckland}

Suspended soil and road dust made by far the largest contribution to Auckland's $\mathrm{PM}_{10}$, on average, accounting for $42 \%$ of the total (Table 4 ). To simplify the analysis, the coarse and fine fractions of suspended soil and road dust were combined to obtain the common source "suspended soil and road dust (SO \& RD)". Compared to Christchurch, Auckland had higher concentrations of crustal elements (Table 1b). Auckland also had higher wind speeds during sampling, $3 \mathrm{~m} \mathrm{~s}^{-1}$ on average. Southwesterly winds were common in Auckland, so the near-by quarry was often upwind of the sampling site. On average, $22 \%$ of Auckland's $\mathrm{PM}_{10}$ came from SS. Diesel and petrol combustion sources were combined to obtain the "vehicle emissions (VE)" source. Auckland's PM $_{10}$ had the same percentage contribution from VE but a significantly lower contribution from DE (14\% on average). The contributions from VE and DE reflected Auckland's relatively large vehicle fleet and moderate 
temperature (that averaged $12{ }^{\circ} \mathrm{C}$ during sampling) that was associated with little dependency on solid fuel combustion for domestic heating. Refining VE, diesel combustion emissions made a nearly twofold higher contribution to the airborne particles than petrol combustion. A typical diesel fueled vehicle in Auckland is reckoned to produce $>20$ times more particulate emissions than a typical petrol fueled vehicle (ARC, 2004). Senaratne and Shooter (2004) reported that, under cold and calm conditions of winter, diesel combustion emissions made a higher contribution than at other times.

For Christchurch, SS and DE made similar contributions to $\mathrm{PM}_{10}$ that accounted for $48 \%$ of the total on average. Probably due to its visible nature, local perception has long held that DE was the only source. Recent environmental policy in Christchurch includes punitive elements and financial incentives to encourage the use of more efficient wood burners for domestic heating during winter. Our analysis may suggest a positive effect of this policy. SO \& RD made the highest percentage contribution to $\mathrm{PM}_{10}(29 \pm 11 \%$ of the total), probably including DE and VE products deposited onto the soil and road surfaces. There was no exposed land near the Christchurch sampling site, so the crustal component probably came mainly from unpaved roads and the weathering and wearing of paved roads. We believe that SO \& RD also included particles related to VE from tyre wear. The VE contribution averaged $23 \pm 4 \%$ of the total. Combining SO \& RD and VE, vehicles accounted for up to half of Christchurch's $\mathrm{PM}_{10}$ and two-thirds of anthropogenic emissions. As in Auckland, diesel combustion emissions made nearly twice the contribution of petrol combustion.

Road transport was a dominant source of $\mathrm{PM}_{10}$ during winter in the two New Zealand cities. For the year when airborne particles were sampled (2001), New Zealand's road transport vehicles consumed 3.2 and 1.8 billion liters of petrol and diesel fuel, respectively (Sriramaratnam, 2004). Ten years earlier, the corresponding values were 2.7 and 0.7 billion liters. The volume of diesel fuel used for road transport thus increased at a rate more than twice that of petrol.

\section{Conclusions}

Analyses were based on $63 \mathrm{PM}_{10}$ samples, use of the source-receptor model was exploratory and our results should be considered preliminary. A possible limitation of this study was the exclusion of nitrogen and organic compounds. Combustion was the principal source of $\mathrm{PM}_{10}$ in both cities during winter and there was no evidence of industrial sources. In Auckland, on average, sea spray was estimated to contribute $22 \%$ of total emissions and domiciles, including home heating, only $14 \%$. Road transport was considered the source of nearly two-thirds of $\mathrm{PM}_{10}$ in Auckland, on average, including vehicle emissions and suspended soil and road dust. This source may have included resuspended particulate matter from home heating emissions, but it was considered unlikely. In Christchurch, sea spray and home heating were $\mathrm{PM}_{10}$ sources of nearly equal contribution at 23 and $25 \%$ of the total, on average, respectively. Road transport was considered the source of about half of $\mathrm{PM}_{10}$ in Christchurch. Road transport was thus a dominant source of $\mathrm{PM}_{10}$ in both cities. During the year of study, New Zealand had a relatively small human population of three million adults, but most 
are affluent and around five billion liters of imported diesel and petrol fuel was consumed for road transport. Our data analysis suggested that the contribution of diesel combustion to $\mathrm{PM}_{10}$ was nearly twice that of petrol combustion.

\section{Acknowledgement}

The Foundation for Science Research and Technology funded this study and a scholarship for the senior author. We thank Dr David Shooter for valuable discussion. Environment Canterbury, Water Care Ltd., Christchurch City Council, Winstone Aggregates, and Auckland Regional Council kindly shared their meteorological data. We thank three anonymous reviewers for their constructive criticism that prompted us to revise and hopefully improve the manuscript.

\section{References}

ARC. (1997), Air pollution in Auckland, http://www.arc.govt.nz.

ARC. (1999), State of the Auckland Region Report, http://www.arc.govt.nz/news/new/state.htm.

ARC. (2002), Auckland Regional growth forum, Auckland Regional Council, http://www.arc.govt.nz/arc/.

ARC. (2004), Motor vehicles. http://www.arc.govt.nz/arc/environment/air/.

Brimblecombe, P. (1996), Air composition and chemistry. Cambridge, UK, Cambridge University Press.

Begum, B.A., Kim, E., Biswas, S.K. and Hopke, P.K. (2004), Investigation of atmospheric particulate matter (APM) at an urban area in Bangladesh. Chemistry Division, Atmos. Environ. 38 (19): $3025-$ 3038

CCC. (2000), Christchurch City update 2000: state of the environmental monitoring report. Christchurch, New Zealand, Christchurch City Council: 125.

Chan, Y., Simpson, R. W., Mctainsh, G. H, Vowls, P. D., Cohen, D. D, and Bailey, G. M. (1999), Sources apportionment of $\mathrm{PM}_{2.5}$ and $\mathrm{PM}_{10}$ aerosols in Brisbane (Australia) by receptor modelling. Atmos. Environ. 33: 3251-3268.

Chow, J.C. (1995), Measurement methods to determine compliance with ambient air quality standards for suspended particles. J. Air \& Waste Manage. Assoc. 45: 320-326.

Cohen, D.D., Taha, G., Stelcer, E., Garton, D. and Box, G. (2000), The measurement and sources of fine particle elemental carbon at several key sites in NSW over the past eight years. 15th International Clean Air \& Environment conference, Sydney, Australia, Clean Air Society of Australia and New Zealand.

CRC. (1996), Canterbury Regional Council land transport strategy 1996-2001. Christchurch, New Zealand, Canterbury Regional Council, 7-41. 
CRC. (1997), Christchurch inventory of total emissions. Christchurch, New Zealand, Canterbury Regional Council.

Davy, P., Markwitz, A. and Trompetter, W. J. (2002), Elemental analysis and source apportionment of ambient particulate matter in the Wellington Region of New Zealand. 16th International Clean Air \& Environment conference, Christchurch, New Zealand, Clean Air Society of Australia and New Zealand.

Fisher, G.W., Thompson, A. and Crushel, G.I. (1998), An overview of the elemental analysis of ambient particulates in New Zealand. Auckland, New Zealand, National Institute of Water \& Atmospheric Research Ltd.

Harrison, Y.M., Smith, J.T. and Luhana, L. (1996), Source apportionment of atmospheric polycyclic aromatic hydrocarbons collected from an urban location in Birmingham, UK. Environ Sci. Tecnol. 30: 825-832.

Hien, P.D., Binh, N.T., Truong, Y. and Ngo, N.T. (1999), Temporal variations of source impacts at the receptor, as derived from air particulate monitoring data in Ho Chi Minh City, Vietnam. Atmos. Environ. 33: 3133-3142.

Huo, X.X., Crisp, P.T. and Cohen, D.D. (1999), Source apportionment of fine particles in the Wollongong-Port Kembla area during 1992 \& 1993. Clean Air 33(1): 26-35.

Kemp, K. (1984), Multivariate analysis of $\mathrm{SO}_{2}$ measured at the Danish EMEP stations. Report MST LUFT-A88, Air Pollution Laboratory, National Agency of Environmental Protection, Denmark.

Lee, E., Chan, C.K. and Paatero, P. (1999), Application of positive matrix factorization in source apportionment of particulate pollutants in Hong Kong. Atmos. Environ. 33: 3201-3212.

Maxwell, J.A., Teesdale, W.J. and Cambell, J.L. (1995), The Guelph PIXE software package ii. Nuclear Instruments and Methods in Physics Research B 95: 407.

Markwitz, A., Aleta, A. and Smodis, B. (2002), IAEA activities in support of air pollution monitoring in Asia and Pacific Region, Better Air Quality in Asian and Pacific Rim Cities, December 2002, Hong Kong.

Markwitz, A., Trompetter, B. and Davy, P. (2003), Better management of the environment, natural resources and industrial growth through isotope and radiation technology, New Zealand Report 2003, IAEA/RCA project co-ordination meeting and conference of Project Participants, Bangkok, Thailand, November 10-14, 2003.

Mayer, T.A. (2000), Curtailing emissions from diesel engines in tunnel construction - Synopsis. http://www.akpf.org/pub/vert_sum en.pdf.

Miller, J.C. and Miller, J.N. (1993), Statistics for analytical chemistry. West Sussex, UK, Ellis Horwood Ltd

Okamoto, S., Hayashi, M., Nakajima, M., Kainuma, Y. and Shiozawa, K. (1990), A factor analysismultiple regression model for source apportionment of suspended particulate matter. Atmos. Environ. 24A(8):2089-2097. 
Ooki, A. Uematsu, M., Muira, K., Nakae, S. (2002), Sources of sodium in atmospheric fine particles. Atmos. Environ. 36:4367-4374.

Pinto, J.P. (2000), Sources, composition and abundance of atmospheric fine and coarse particles. $J$. Aerosol Sci. 31(Supply.1): 108-109.

Scott, A.J. (2004), Chemical characterization and source apportionment of fine particles in Christchurch, New Zealand: Part 1 - Modeling by positive matrix factorization, Proceedings of the $13^{\text {th }}$ World Clean Air \& Environmental Protection Congress \& Exhibition, London, UK, International Union of Air Pollution Prevention \& Environmental Protection Association, August $22-27.2004$

Senaratne, I. (1999), An investigation of hydrocarbon compounds and metals in the Christchurch atmosphere, and their sources. MSc Thesis in Environmental Science. University of Canterbury, Christchurch, New Zealand.

Senaratne, I. (2003), Chemical characterization of airborne particulate matter in New Zealand cities. $\mathrm{PhD}$ thesis, The University of Auckland.

Senaratne, I. and Shooter, D. (2004), Elemental composition in source identification of brown haze in Auckland, New Zealand. Atmos. Environ. 38: 3049-3059.

Sharma, V.K., Patil, R.S. (1994), Chemical mass balance model for source apportionment of aerosols in Bombay. Environmental Monitoring and Assessment 29: 75-88.

Song, Y., Tang, X., Fang, C., Zhang, Y., Hu, M. and Zeng, L. (2002), Source apportionment of fine particles in Beijing. (article in Chinese) Huan Jing Ke Xue, Nov 23(6): 11-16.

Spronken-Smith, R.A., Sturman, A.P. and Wilton, E.V. (2002), The air pollution problem in Christchurch, New Zealand - Progress and prospectus. Clean Air 36(1): 23-29.

Sriramaratnam, R. (2004), Ministry of Economic Development New Zealand. Wellington, New Zealand. Personal communication.

Swietlicki, E., Puri, S., Hansson, H.C. and Edner, H. (1996), Urban air pollution source apportionment using a combination of aerosol and gas monitoring techniques. Atmos. Environ. 30(15): 2795-2809.

Thompson, A. and Fisher, G.W. (1998), Visibility degradation in New Zealand: Elemental fingerprints of particulates for source apportionment, National Institute of Water \& Atmospheric Research Ltd. NIWA Report AK96094.

Trompetter, W.J., Markwitz, A. and Davy, P. (2000a), Using ion beam analysis to characterise sources of air particulate in the Wellington region of New Zealand. 15th International Clean Air \& Environment conference, Sydney, Australia, Clean Air Society of Australia and New Zealand.

Trompetter, W.J., Markwitz, A. and Davy, P. (2000b), Air particulate analysis in New Zealand with ion beam analysis: correlation of elemental finger prints with meteorological data in the Wellington Region. 15th International Clean Air \& Environment Conference, Sydney, Australia, Clean Air Society of Australia and New Zealand. 
Trompetter, W.J. and Markwitz, A. (2001), Ion beam analysis results of air particulate matter collected in the Auckland region. Lower Hutt, New Zealand, Institute of Geological \& Nuclear Sciences Limited.

Trompetter, W.J., Markwitz, A. and Davy, P. (2002), Characterization of ambient air particulate matter from lead free vehicles in New Zealand. 4th Bio PIXE Conference, Mexico.

Wang, H.B., (2002), Water-soluble inorganic ions in atmospheric particles in New Zealand urban areas. PhD Thesis, The University of Auckland.

Worldbank1. (2004), Understanding sources of airborne particles. http://nweb18.worldbank.org/sar/sa.nsf/Attachments/Chapter4/\$File/Chapter+4.pdf.

Worldbank2. (2004), Urban Air Pollution, South Asia Urban Air Qaulity Management Briefing Note No.4. What do we know about air pollution? - India case study. http://nweb18.worldbank.org/sar/sa.nsf/Attachments/Briefing4/\$File/Note+4+India+air+pollution. pdf.

Zhang, Y., Zhu, X., Slania, S., Shao, M., Zeng, L., Hu, M., Bergin, M. and Salmon, L. (2004), Aerosol pollution in some Chinese cities. Pure and Applied Chemistry 76(6): 1227-1239.

Zhang, X.Y., An, Z.S. (2004), Particulate atmospheric pollution and control in Xian. http://www.eetpc.org/Air\%20Quality/PAPERS.AIR/zhang.htm

Received for review, March 8, 2005

Accepted, April 19, 2005 